Running title: Cancer screening

\title{
Uptake and correlates of cervical and breast cancer screening among women in Jordan: national results of the 2017-2018 Population and Family Health Survey
}

Supa Pengpid ${ }^{1,2}$, Karl Peltzer, ${ }^{3}$ Chao Zhang ${ }^{4}$

${ }^{1}$ ASEAN Institute for Health Development, Mahidol University, Salaya, Phutthamonthon, Nakhon Pathom, Thailand;

${ }^{2}$ Department of Research Administration and Development, University of Limpopo, Polokwane, South Africa

${ }^{3}$ Department of Psychology, University of the Free State, Bloemfontein, South Africa

${ }^{4}$ Department of Bone and Soft Tissue Tumors, Tianjin Medical University Cancer Institute and Hospital, National Clinical Research Center for Cancer, Key Laboratory of Cancer Prevention and Therapy, Tianjin's Clinical Research Center for Cancer, Tianjin, China

Corresponding author at: Karl Peltzer, University of the Free State, Bloemfontein, South Africa; Email: kfpeltzer@gmail.com

\begin{abstract}
The study aimed to estimate the prevalence and associated factors of cervical and breast cancer screening among women in the general population in Jordan. Nationally representative cross-sectional data were analysed from 14,689 women (34 years median age, range 15-49) that took part in the "2017-18 Jordan Population and Family Health Survey". Information about cancer screening uptake included Pap smear, clinical breast examination, and mammography. Results indicate that the prevalence of ever Pap smear cancer screening was $15.3 \%$, clinical breast examination in the past 12 months $13.9 \%$ and ever mammography $8.7 \%$. In adjusted logistic regression analysis, older age, higher wealth, greater media exposure and tobacco use were positively and being Syrian, and living in the southern region were negatively associated with ever Pap smear, clinical breast examination in the past 12 months, and ever mammography. In addition, high decision-making power was associated with the uptake of Pap smear and higher education was associated with ever mammography. The study showed a low cancer screening
\end{abstract}


uptake, and several factors were identified that can assist in promoting cancer screening in Jordan.

Keywords: screening, cervical cancer, breast cancer, women, Jordan

\section{Introduction}

"Breast cancer is the most frequent cancer among women, impacting 2.1 million women each year, and also causes the greatest number of cancer-related deaths among women." (WHO, 2020a) "Cervical cancer is the fourth most frequent cancer in women with an estimated 570,000 new cases in 2018 representing 6.6\% of all female cancers. Approximately $90 \%$ of deaths from cervical cancer occurred in low- and middle-income countries." (WHO, 2020b) In the Eastern Mediterranean region, "the most common cancers among women are breast (34.7\%), colorectal (5.7\%) and cervical cancer (4.6\%)" (Pourghazian et al., 2019). In Jordan, the most common cancers among women are breast (36.4\%), colorectal 10.9\%, thyroid 6.4\% and corpus uteri $4.3 \%$ (WHO, 2018). In Jordan, the age-standardized incidence of breast cancer was 57.4 pro 100000 and corpus uteri 7.9 per 100000 (WHO, 2018). Crucial in the fight against "cervical and breast cancer is the early detection and treatment" (Sankaranarayanan, 2014), yet "organized cancer screening is lacking in most of countries of the Extended Middle East and North Africa Region, the majority of cervical cancers are diagnosed late, leading to high mortality, and women face many political, cultural, and financial barriers to gaining access to screening." (Sancho-Garnier et al., 2013, p.G51).

In a few local surveys in Jordan, low uptake of cancer screening among women has been reported. For example, 31.2\% of 500 married Jordanian women (21 to 65 years) in Amman had been screened for cervical cancer (Al-Amro et al., 2020), 87.6\% of 507 women (40-69 years) in six governorates in Jordan had never undergone mammography screening (Abu-Helalah et al., 2015) and in a study in 2018 among 612 women (18-63 years), 38\% had had a smear test before. (Asali et al., 2020). Moreover, in a national survey among women (20-49 years) in Jordan in 2012, the prevalence of clinical breast examination in the past 12 months was $19.3 \%$ and lifetime Pap-smear testing 25.5\% (Al Rifai \& Nakamura, 2015), and in a national survey ( $\mathrm{N}=1549)$ in 2011 in Jordan among women ( $\geq 18$ years), 7\% had ever undergone mammography (Othman et al., 2015). As part of the national Demographic and Health Surveys in 18 countries (women 1549 years) the prevalence of the utilization of cervical cancer screening was 29.2\%, (Mahumud et al., 2020), including in Egypt (97.4\%), and India (27.2\%) (Mahumud, et al., 2020), and in 
Turkey 22.0\% (Sözmen et al., 2016). In women 30 years and older in Turkey $19.0 \%$ ever had a mammography (Sözmen et al., 2016) and in South Africa 13.4\% ever had mammography (Phaswana \& Peltzer, 2018). In Brunei Darussalam, the prevalence of a pap smear test (women 18-69 years) was 56.5\%, mammography (women 18-69 years) $11.3 \%$, and clinical breast examination $(=\mathrm{CBE})($ women $18-69$ years) $56.2 \%$ (Pg Suhaimi et al., 2020).

In an integrative review of CCS in Middle Eastern and Western Asian Arab countries, Ali, Skirton, Clark, and Donaldson (2017, p.414) found that "few population-based cervical cancer screening programs had been implemented, with low knowledge of, and perceptions about, cervical screening among Arab women, the majority of whom are Muslim.” In a study among women in Jordan, the most commonly reported barriers for women who never underwent mammography were: "fear of results (63.8\%); no support from surrounding environment (59.7); cost of the test (53.4\%); and religious belief, i.e. Qadaa Wa Qadar (51.1\%)." (Abu-Helalah et al., 2015). There seems to be a lack of recent national population-based information on cervical and breast cancer screening and its correlates among women in Jordan, an upper middle-income country in the Middle East.

As reviewed previously (in Pengpid \& Peltzer, 2018), factors associated with cervical and/or breast cancer screening may include "higher socioeconomic position, urban living, increased access to health care, having chronic conditions, positive lifestyle behaviours such as physical activity, fruit and vegetable consumption, and not smoking, having mental distress or illness or having depressive symptoms, having obesity and poor self-rated health status." In addition, having a health insurance (Mahumud et al., 2020; Tiruneh et al., 2017), media exposure (Al Rifai \& Nakamura, 2015; Mahumud et al., 2020), sexual autonomy (Tiruneh et al., 2017), tobacco use (Al Rifai \& Nakamura, 2015), living in the central and nothern region in Jordan (Al Rifai \& Nakamura, 2015) were associated with clinical breast examination and/or cervical cancer screening. This study aimed to determine the prevalence and correlates of cervical and breast cancer screening in a national survey in Jordan in 2017-2018.

\section{Method}

\section{Sample and procedure}

The study is based on a national population-based cross-sectional survey of ever-married women age 15-49 (2017-18 Jordan Population and Family Health Survey= JPFHS) in Jordan. The 
dataset is publically available and study procedures and sampling strategy have been described in detail (DOS, 2019). A “stratified multistage cluster sampling design" was used to generate a sample that is nationally representative, "for urban and rural areas, for the country's three regions (Central, North, and South) and 12 governorates, and for three national groups (Jordanians, Syrians, and individuals of other nationalities" (DOS, 2019). The household and individual response rate was $98 \%$ and 99\%, respectively (DOS, 2019). The survey protocol was approved by the ICF Institutional Review Board, and written informed consent was obtained from all participants prior to the investigation (DOS, 2019).

\section{Measures}

Outcomes variables included, ever had a Pap test, breast cancer examination by a specialist in the past 12 months, and ever had a mammogramme. Reasons for never having had a mammogramme were asked with a structured question ("no, need, not sick, no symptom, fear of results, no support from family/husband, too far, too expensive, other, don't know") (DOS, 2019).

Sociodemographic variables included educational level, age, sex, nationality, region, residence status and wealth quintiles based on a household asset list (DOS, 2019).

Other co-variates included, health insurance cover (Yes, No); Decision making power in relation to woman's health, large household purchases, and visits to friends or family (high decision making power was defined as alone or jointly with husband, and other responses as low decision making power) (Tiruneh et al., 2017); media exposure included newspaper, radio, TV (each at least once a week), and internet use past year. Responses were summed and classified as 0-1, 2 and 3-4 types of media exposure. Smokes cigarettes (Yes, No), smokes water pipe (Yes, No) (DOS, 2019).

\section{Data analysis}

Considering the clustered study design, data analyses were conducted with "STATA software version 15.0 (Stata Corporation, College Station, TX, USA).” Adjusted logistic regression identified predictors of ever Pap smear, past 12-month breast clinical examination, and ever mammography. $\mathrm{P}$ values of below 0.05 were accepted as significant and missing values were excluded from the analysis. 


\section{Results}

\section{Sample and cancer screening characteristics}

The sample included 14,689 women (34 years median age, IQE 28-44, range 15-49), 72.4\% had secondary or higher education, $8.6 \%$ were Syrian, and $89.9 \%$ lived in urban areas. More than half of the participants (58.3\%) had a health insurance cover, 25.2\% had exposure to three or for media types, $90.5 \%$ had high decision-making power and $12.0 \%$ were tobacco users. The prevalence of ever Pap smear cancer screening was $15.3 \%$, clinical breast examination in the past 12 months $13.9 \%$ and ever mammography $8.7 \%$ (see Table 1).

Table 1

\section{Associations with cancer screening among women in Jordan}

In adjusted logistic regression analysis, older age, higher wealth, greater media exposure and tobacco use were positively and being Syrian, and living in the southern region were negatively associated with ever Pap smear, clinical breast examination in the past 12 months, and ever mammography. In addition, high decision-making power was associated with the uptake of Pap smear and higher education was associated with ever mammography (see Table 2).

Table 2

Reasons for never having had a mammogramme included no need (50.1\%), not sick (23.5\%), no symptom (14.7\%), fear of results (4.4\%), no support from family or husband $(2.2 \%)$, too far $(1.3 \%)$ and too expensive $(0.9 \%)$.

\section{Discussion}

In this 2017-2018 national population-based survey among women (15-49 years) in Jordan, the prevalence of ever CCS (15.3\%) was lower than in the 2012 national survey in Jordan (18.8\%, women 15-49 years) (Al Rifai \& Nakamura, 2015), a local survey in Amman, Jordan (31.2\%, 21-65 years) (Al-Amro et al., 2020) and another local survey in Jordan (38\%, 1863 years) (Asali et al., 2020). The CCS prevalence rate in Jordan was also lower than the national 
Demographic and Health Surveys in 18 countries (29.2\%) (Mahumud et al., 2020), Egypt (97.4\%) (Mahumud et al., 2020), Turkey (22.0\%, 30 years and older) (Sözmen et al., 2016) and India (27.2\%) (Mahumud et al., 2020). The prevalence of past 12-month CBE (13.9\%) in this study was lower than in the 2012 Jordan national survey (19.3\%) (Al Rifai \& Nakamura, 2015) and in Brunei Darussalam STEPS survey (ever 56.2\%, 18-69 years) (Pg Suhaimi et al., 2020). The prevalence of ever mammography screening $(8.7 \%)$ in this study was similar to a 2011 national survey among women ( $\geq 18$ years) in Jordan (7\%) (Othman et al., 2015), and lower than in a study in six governorates in Jordan (12.4\%, 40-64 years) (Abu-Helalah et al., 2015) and lower than in Turkey (19.0\%, $\geq 30$ years) (Sözmen et al., 2016) and in South Africa (13.4\%, $\geq 30$ years) (Phaswana \& Peltzer, 2018) and Brunei Darussalam (11.3\%, 18-69 years) (Pg Suhaimi et al., 2020). CBE and mammography screening fall short of national recommendations for women at normal risk in Jordan (for $\mathrm{CBE} \geq 25$ years yearly, and mammogramme $\geq 40$ years yearly) (Jordan Breast Cancer Program, 2019), and cervical cancer screening fall short of Jordanian guidelines (annual Pap smear, $\geq 21$ years) (DOS, 2019) and the US Preventive Services Task Force (USPSTF) 2012 recommendations (screening for cervical cancer every 3 years with cervical cytology alone in women aged 21 to 65 years) (US Preventive Services Task Force, 2018). Low uptake of cervical cancer screening may be attributed to lack of awareness or understanding, the "low incidence of cervix cervical cancer in Jordan and the fact that it is primarily caused by HPV infection, a sexually transmitted disease believed to be uncommon in a conservative Muslim country." (Al-amro et al., 2020; Al Nsour et al., 2012). Reasons for the low uptake of CBE and mammography may be related to low knowledge on mammography, many Jordanian women do not believe it the benefits of mammography (Al Nsour et al., 2012). Major barriers to access mammography in this study were no need (50.1\%), not sick (23.5\%), no symptom (14.7\%), fear of results (4.4\%), no support from family or husband (2.2\%), too far $(1.3 \%)$ and too expensive $(0.9 \%)$, while in a previous study in Jordan, major barriers were "fear of results (63.8\%); no support from surrounding environment (59.7); cost of the test (53.4\%); and religious belief, i.e. Qadaa Wa Qadar (51.1\%)" (Abu-Helalah et al., 2015). Health education should include the benefits and misconceptions of cancer screening (Abu-Helalah et al., 2015).

The study showed that the 30-49 year-old age group was more likely to have undergone CCS than the younger age group, which is consistent with the recommendations of the World Health Organization (2013), prioritizing cervical cancer screening of women aged 30 to 49 years. 
Mammography and CBE were more likely in the 30-49 year-old age group in this study, which is in line with the Jordanian recommendations on breast cancer screening (Jordan Breast Cancer Program, 2019). Consistent with some previous research (Al Rifai \& Nakumara, 2015; Mahumud et al., 2018; Sözmen et al., 2016; Williams-Brennan et al., 2012), this study showed that a higher socioeconomic position (higher wealth status and higher education) and greater media exposure increased the odds for CCS, CBE and/or mammography. It is possible that women who are wealthier, have higher education and greater media exposure have better knowledge of the health risks related to cancer and therefore engage more likely in cancer screening (Al Rifai \& Nakumara, 2015; Ampofo et al., 2020). In another study in Jordan that investigated the "public use of different media and channels for seeking health/cancer-related information," health service providers and TV were found the most trusted sources and may therefore be effective tools for health education (Akhu-Zaheya et al., 2014). Unlike some previous studies, including in Jordan (Al Rifai \& Nakamura, 2015; Mahumud et al., 2020; Phaswana-Mafuya \& Peltzer, 2018; Tiruneh et al., 2017), this study did not show that having a health insurance and urban residence increased the odds for cancer screening.

As shown in the 2012 Jordan national survey (Al Rifai \& Nakamura, 2015), in this study, living in the southern region decreased the odds for cancer screening and tobacco use increased the odds for cancer screening. In an earlier study in 2007 in Jordan, the lower uptake of CBE and Pap smear in the Southern region in Jordan was attributed to inadequate health services coverage, e.g., due to shortage of qualified trained staff (Al Nsour et al., 2012). In the 2012 Jordan national survey (Al Rifai \& Nakamura, 2015), tobacco use among women was also associated with CBE but not with CCS, while in national US health interview surveys never smokers were less likely to take up cancer screening than current smokers (Sanford et al., 2019). Some previous research showed that the practice of other positive lifestyle behaviours apart from CCS increased the odds for CCS (Sözmen et al., 2016; Theme Filha et al., 2016), however, this was not confirmed in this study for non-current smokers.

Compared to women with Jordanian nationality, Syrian women had significantly lower odds to uptake cancer screening (CCS, CBE and mammography). Syrian refugees in Jordan may be disproportionally affected by cancer and have decreased access to cancer screening services (Mansour et al., 2010). All the more, Syrian women and women living in the Southern region should be particularly targeted in improving cancer-screening uptake. In line with some previous 
research (Tiruneh et al., 2017), this study found that high decision-making power was associated with CCS. Similar results were found about cancer screening among Vietnamese American women (Nguyen et al., 2014). "It is possible that the sense of control these women feel over their lives includes control over their health care practices" (Nguyen et al., 2014).

The study limitations included that this investigation was limited due to the self-report of data and the cross-sectional survey design. An additional limitation was that the JPFHS in Jordan did not assess awareness cancer screening, information sources about cancer screening, risk perception about cancer, family history of cancer, and accessibility of cancer screening, which should be included in future studies.

\section{Conclusion}

The study showed a low cancer screening uptake (Pap smear, mammography, and clinical breast examination). Several protective factors were identified for cancer screening such as older age, higher wealth, higher education, greater media exposure, decision-making power, not being Syrian and not residing in the Southern region of the country, that could assist in programmes promoting cervical and breast cancer screening.

\section{Acknowledgment}

The authors thank the DHS Program Demographic and Health Surveys for the data used in this study.

\section{References}

Abu-Helalah MA, Alshraideh HA, Al-Serhan AA, Kawaleet M, Nesheiwat AI. Knowledge, barriers and attitudes towards breast cancer mammography screening in jordan. Asian Pac J Cancer Prev. 2015;16(9):3981-3990. doi:10.7314/apjcp.2015.16.9.3981

Akhu-Zaheya LM, Jagbir MT, Othman A, Ahram M. Media use for seeking health/cancerrelated information: findings from knowledge, attitudes and practices towards cancer prevention and care survey in Jordan. Int J Nurs Pract. 2014;20(6):608-615. doi:10.1111/ijn.12196 
Al Nsour M, Brown DW, Tarawneh M, Haddadin R, Walk H. Breast and Cervical Cancer Screening Among Women in Jordan: Findings from the Behavioural Risk Factor Surveillance System - 2007. The Open Breast Cancer Journal, 2012, 4: 1-7. DOI: $10.2174 / 1876817201204010001$

Al Rifai, R., \& Nakamura, K. (2015). Differences in breast and cervical cancer screening rates in Jordan among women from different socioeconomic strata: Analysis of the 2012 population-based household survey. Asian Pacific Journal of Cancer Prevention, 16, 6697704.

Al-Amro SQ, Gharaibeh MK, Oweis AI. Factors Associated with Cervical Cancer Screening Uptake: Implications for the Health of Women in Jordan. Infect Dis Obstet Gynecol. 2020;2020:9690473. Published 2020 Mar 21. doi:10.1155/2020/9690473

Ali, S., Skirton, H., Clark, M. T., \& Donaldson, C. (2017). Integrative review of cervical cancer screening in Western Asian and Middle Eastern Arab countries. Nursing \& Health Sciences, 19(4), 414-426. https://doi.org/10.1111/nhs.12374

Ampofo, A. G., Adumatta, A. D., Owusu, E., \& Awuviry-Newton, K. (2020). A cross-sectional study of barriers to cervical cancer screening uptake in Ghana: An application of the health belief model. PloS one, 15(4), e0231459. https://doi.org/10.1371/journal.pone.0231459

Asali F, Abdel-Razeq R, Al-Thunaibat A, Okour A, Abu Mahfouz S, Abu Mahfouz I. Jordanian women's attitudes towards cervical cancer screening: has the pattern changed?. J Obstet Gynaecol. 2020;40(4):564-568. doi:10.1080/01443615.2019.1635097

Department of Statistics (DOS) and ICF. 2019. Jordan Population and Family and Health Survey 2017-18. Amman, Jordan, and Rockville, Maryland, USA: DOS and ICF.

Jordan Breast Cancer Program. National guidelines. Recommendations for women in Jordan at normal risk, 2019. URL: http://www.jbcp.jo/understandingbreastcancer/55

Mahumud, R. A., Keramat, S. A., Ormsby, G. M., Sultana, M., Rawal, L. B., Alam, K., ..., Renzaho, A. (2020). Wealth-related inequalities of women's knowledge of cervical cancer screening and service utilisation in 18 resource-constrained countries: evidence from a pooled decomposition analysis. International Journal for Equity in Health, 19(1), 42. https://doi.org/10.1186/s12939-020-01159-7

Mansour A, Al-Omari A, Sultan I. Burden of Cancer Among Syrian Refugees in Jordan. J Glob Oncol. 2018;4:1-6. doi:10.1200/JGO.18.00132 
Nguyen AB, Clark TT, Belgrave FZ. Gender roles and acculturation: relationships with cancer screening among Vietnamese American women. Cultur Divers Ethnic Minor Psychol. 2014;20(1):87-97. doi:10.1037/a0033474

Othman A, Ahram M, Al-Tarawneh MR, Shahrouri M. Knowledge, attitudes and practices of breast cancer screening among women in Jordan. Health Care Women Int. 2015;36(5):578592. doi:10.1080/07399332.2014.926900

Pengpid, S. \& Peltzer, K. (2018) Prevalence and risk factors for cervical and breast cancer screening among women in the general population in Indonesia. Gender and Behaviour, 16(3), 11994-12003.

Pg Suhaimi, A., Abdul Rahman, H., Ong, S. et al. Predictors of non-communicable diseases screening behaviours among adult population in Brunei Darussalam: a retrospective study. J Public Health (Berl.) (2020). https://doi.org/10.1007/s10389-020-01240-z

Phaswana-Mafuya, N., \& Peltzer, K. (2018). Breast and Cervical Cancer Screening Prevalence and Associated Factors among Women in the South African General Population. Asian Pacific Journal of Cancer Prevention, 19(6), 1465-1470. doi:10.22034/APJCP.2018.19.6.1465

Pourghazian, N., Sankaranarayanan, R., Alhomoud, S., \& Slama, S. (2019). Strengthening the early detection of common cancers in the Eastern Mediterranean Region. Eastern Mediterranean Health Journal, 25(11), 767-768. https://doi.org/10.26719/2019.25.11.767

Sancho-Garnier, H., Khazraji, Y. C., Cherif, M. H., Mahnane, A., Hsairi, M., El Shalakamy, A., ... Seoud, M. (2013). Overview of cervical cancer screening practices in the extended Middle East and North Africa countries. Vaccine, 31 Suppl 6, G51-G57.

Sanford NN, Sher DJ, Butler S, et al. Cancer screening patterns among current, former, and never smokers in the United States, 2010-2015. JAMA Netw Open. 2019;2(5):e193759. doi:10.1001/jamanetworkopen.2019.3759

Sankaranarayanan, R. (2014). Screening for cancer in low- and middle-income countries. Annals of Global Health, 80, 412-7.

Sözmen, K., Unal, B., Sakarya, S., Dinc, G., Yardim, N., Keskinkilic, B., \& Ergör, G. (2016). Determinants of breast and cervical cancer screening uptake among women in Turkey. Asia-Pacific Journal of Public Health, 28, 528-38. 
Theme Filha, M. M., Leal, M. D., Oliveira, E. F., Esteves-Pereira, A. P., \& Gama, S. G. (2016). Regional and social inequalities in the performance of Pap test and screening mammography and their correlation with lifestyle: Brazilian national health survey, 2013. International Journal for Equity in Health, 15, 136.

Tiruneh FN, Chuang KY, Ntenda PAM, Chuang YC. Individual-level and community-level determinants of cervical cancer screening among Kenyan women: a multilevel analysis of a Nationwide survey. BMC Womens Health. 2017;17(1):109. Published 2017 Nov 15. doi:10.1186/s12905-017-0469-9

US Preventive Services Task Force, Curry SJ, Krist AH, et al. Screening for Cervical Cancer: US Preventive Services Task Force Recommendation Statement. JAMA. 2018;320(7):674686. doi:10.1001/jama.2018.10897

Williams-Brennan, L., Gastaldo, D., Cole, D. C., \& Paszat, L. (2012). Social determinants of health associated with cervical cancer screening among women living in developing countries: a scoping review. Archives of Gynecology and Obstetrics, 286, 1487-505.

World Health Organization (WHO) (2013). WHO guidelines for screening and treatment of precancerous lesions for cervical cancer prevention. URL: https://apps.who.int/iris/bitstream/handle/10665/94830/9789241548694_eng.pdf?sequence $=1$ (accessed 24 August 2020).

World Health Organization. Global cancer observatory. Jordan, 2018. URL: https://gco.iarc.fr/today/data/factsheets/populations/400-jordan-fact-sheets.pdf

World Health Organization (WHO) (2020a). Breast cancer. URL: https://www.who.int/cancer/prevention/diagnosis-screening/breast-cancer/en/ (accessed 2 June 2020)

World Health Organization (WHO) (2020b) Cervical cancer. URL: https://www.who.int/cancer/prevention/diagnosis-screening/cervical-cancer/en/(accessed 2 June 2020) 
Table 1: Sample and cancer screening characteristics of women, Jordan, 2017/2018

\begin{tabular}{|c|c|c|c|c|}
\hline Variable & Sample & $\begin{array}{l}\text { Ever Pap } \\
\text { smear }\end{array}$ & $\begin{array}{l}\text { Breast } \\
\text { exam past } \\
12 \text { months }\end{array}$ & $\begin{array}{c}\text { Ever } \\
\text { mammography }\end{array}$ \\
\hline & $\mathrm{N}(\%)$ & $\mathrm{N}(\%)$ & $\mathrm{N}(\%)$ & $\mathrm{N}(\%)$ \\
\hline All & 14689 & $1783(15.3)$ & $1642(13.9)$ & $1080(8.7)$ \\
\hline $\begin{array}{l}\text { Age in years } \\
15-19 \\
20-24 \\
25-29 \\
30-34 \\
35-39 \\
40-44 \\
45-49\end{array}$ & $\begin{array}{l}427(2.5) \\
1640(10.5) \\
2612(16.9) \\
2748(18.6) \\
2545(18.0) \\
2386(17.1) \\
2331(16.5)\end{array}$ & $\begin{array}{l}4(1.4) \\
63(5.0) \\
168(7.9) \\
275(12.7) \\
356(17.3) \\
443(22.5) \\
474(24.7)\end{array}$ & $\begin{array}{l}4(1.3) \\
92(7.1) \\
186(8.5) \\
290(13.3) \\
331(17.0) \\
340(17.5) \\
399(19.4)\end{array}$ & $\begin{array}{l}0(0.0) \\
61(3.8) \\
120(5.3) \\
162(6.9) \\
181(8.7) \\
244(12.2) \\
312(15.3)\end{array}$ \\
\hline $\begin{array}{l}\text { Education } \\
\text { None } \\
\text { Elementary } \\
\text { Prepatory } \\
\text { Secondary } \\
\text { Higher } \\
\end{array}$ & $\begin{array}{l}507(2.5) \\
1438(9.1) \\
2262(15.9) \\
6113(41.1) \\
3410(31.3) \\
\end{array}$ & $\begin{array}{l}34(9.4) \\
110(12.3) \\
275(15.5) \\
737(14.4) \\
528(18.2) \\
\end{array}$ & $\begin{array}{l}41(10.2) \\
114(10.8) \\
246(13.3) \\
640(11.2) \\
498(19.0) \\
\end{array}$ & $\begin{array}{l}31(7.0) \\
69(7.2) \\
155(7.0) \\
398(6.6) \\
353(13.0) \\
\end{array}$ \\
\hline $\begin{array}{l}\text { Nationality } \\
\text { Jordanian } \\
\text { Syrian } \\
\text { Other nationality }\end{array}$ & $\begin{array}{l}12390(86.9) \\
1703(8.6) \\
596(4.5)\end{array}$ & $\begin{array}{l}1676(16.5) \\
58(5.8) \\
49(10.4)\end{array}$ & $\begin{array}{l}1481(14.8) \\
71(5.2) \\
90(14.3)\end{array}$ & $\begin{array}{l}988(10.1) \\
38(6.7) \\
54(5.3)\end{array}$ \\
\hline $\begin{array}{l}\text { Wealth quintile } \\
\text { Lowest } \\
\text { Low } \\
\text { Middle } \\
\text { High } \\
\text { Highest } \\
\end{array}$ & $\begin{array}{l}4312(20.0) \\
3668(20.7) \\
3089(21.0) \\
2261(20.5) \\
1359(17.9) \\
\end{array}$ & $\begin{array}{l}278(9.3) \\
376(11.5) \\
445(16.3) \\
401(18.1) \\
283(22.0) \\
\end{array}$ & $\begin{array}{l}309(9.4) \\
340(10.6) \\
363(11.9) \\
348(15.5) \\
282(23.5) \\
\end{array}$ & $\begin{array}{l}198(4.8) \\
204(6.1) \\
239(7.7) \\
244(10.2) \\
195(15.7) \\
\end{array}$ \\
\hline $\begin{array}{l}\text { Region } \\
\text { Central } \\
\text { North } \\
\text { South }\end{array}$ & $\begin{array}{l}5244(35.7) \\
5128(34.9) \\
4317(29.4)\end{array}$ & $\begin{array}{l}726(16.4) \\
719(15.2) \\
338(8.4)\end{array}$ & $\begin{array}{l}680(15.6) \\
636(12.4) \\
326(7.6)\end{array}$ & $\begin{array}{l}484(10.1) \\
365(6.7) \\
231(5.3)\end{array}$ \\
\hline $\begin{array}{l}\text { Residence } \\
\text { Rural } \\
\text { Urban } \\
\end{array}$ & $\begin{array}{l}2944(10.1) \\
11745(89.9) \\
\end{array}$ & $\begin{array}{l}303(12.7) \\
1480(15.6)\end{array}$ & $\begin{array}{l}297(13.1) \\
1345(14.0)\end{array}$ & $\begin{array}{l}187(7.0) \\
893(8.9) \\
\end{array}$ \\
\hline $\begin{array}{l}\text { Health insurance cover } \\
\text { No } \\
\text { Yes }\end{array}$ & $\begin{array}{l}4360(41.7) \\
10329(58.3)\end{array}$ & $\begin{array}{l}482(14.8) \\
1301(15.6)\end{array}$ & $\begin{array}{l}477(13.3) \\
1165(14.4)\end{array}$ & $\begin{array}{l}302(7.9) \\
778(9.3)\end{array}$ \\
\hline $\begin{array}{l}\text { Media exposure } \\
0-1 \\
2 \\
3-4\end{array}$ & $\begin{array}{l}5962(33.7) \\
5948(41.1) \\
2779(25.2) \\
\end{array}$ & $\begin{array}{l}551(11.9) \\
776(15.7) \\
456(19.0) \\
\end{array}$ & $\begin{array}{l}513(10.9) \\
659(12.3) \\
470(20.6) \\
\end{array}$ & $\begin{array}{l}356(6.7) \\
416(7.5) \\
308(13.5) \\
\end{array}$ \\
\hline $\begin{array}{l}\text { Decision making power } \\
\text { Low } \\
\text { High }\end{array}$ & $\begin{array}{l}1554(9.5) \\
12180(90.5)\end{array}$ & $\begin{array}{l}134(10.1) \\
1550(16.0)\end{array}$ & $\begin{array}{l}124(9.5) \\
1415(14.4)\end{array}$ & $\begin{array}{l}95(7.1) \\
911(8.9) \\
\end{array}$ \\
\hline $\begin{array}{l}\text { Smoking water pipe and/or cigarettes } \\
\text { No } \\
\text { Yes }\end{array}$ & $\begin{array}{l}13453(88.0) \\
1236(12.0)\end{array}$ & $\begin{array}{l}1576(14.4) \\
207(21.6)\end{array}$ & $\begin{array}{l}1445(13.4) \\
197(18.2)\end{array}$ & $\begin{array}{l}930(8.1) \\
150(13.6)\end{array}$ \\
\hline
\end{tabular}


Table 2: Associations with cancer screening among women in Jordan, 2017/2018

\begin{tabular}{|c|c|c|c|}
\hline Variable & Ever Pap smear & $\begin{array}{c}\text { Breast exam past } 12 \\
\text { months }\end{array}$ & Ever mammography \\
\hline & AOR $(95 \% \mathrm{CI})$ & AOR $(95 \% \mathrm{CI})$ & AOR $(95 \% \mathrm{CI})$ \\
\hline $\begin{array}{l}\text { Age in years } \\
15-29 \\
30-49\end{array}$ & $\begin{array}{l}1 \text { (Reference) } \\
3.22(2.62,3.96)^{* * *}\end{array}$ & $\begin{array}{l}1 \text { (Reference) } \\
2.32(1.86,2.89) * * *\end{array}$ & $\begin{array}{l}1 \text { (Reference) } \\
2.32(1.77,3.03) * * *\end{array}$ \\
\hline $\begin{array}{l}\text { Education } \\
\text { None/Elementary/Prepatory } \\
\text { Secondary } \\
\text { Higher }\end{array}$ & $\begin{array}{l}1 \text { (Reference) } \\
0.93(0.77,1.13) \\
0.98(0.79,1.22)\end{array}$ & $\begin{array}{l}1 \text { (Reference) } \\
0.81(0.66,1.00) \\
1.18(0.94,1.48) \\
\end{array}$ & $\begin{array}{l}1 \text { (Reference) } \\
0.82(0.63,1.07) \\
1.32(1.01,1.73)^{*}\end{array}$ \\
\hline $\begin{array}{l}\text { Nationality } \\
\text { Jordanian } \\
\text { Syrian } \\
\text { Other nationality } \\
\end{array}$ & $\begin{array}{l}1 \text { (Reference) } \\
0.47(0.30,0.74)^{* * *} \\
0.69(0.44,1.09)\end{array}$ & $\begin{array}{l}1 \text { (Reference) } \\
0.46(0.30,0.70)^{* * *} \\
1.12(0.76,1.65)\end{array}$ & $\begin{array}{l}1 \text { (Reference) } \\
0.50(0.30,0.86)^{*} \\
0.86(0.54,1.38)\end{array}$ \\
\hline $\begin{array}{l}\text { Wealth quintile } \\
\text { Lowest/Low } \\
\text { Middle } \\
\text { High/Highest }\end{array}$ & $\begin{array}{l}1 \text { (Reference) } \\
1.42(1.16,1.74)^{* * *} \\
1.62(1.32,2.00)^{* * *}\end{array}$ & $\begin{array}{l}1 \text { (Reference) } \\
1.04(0.83,1.29) \\
1.46(1.17,1.83)^{* * *}\end{array}$ & $\begin{array}{l}1 \text { (Reference) } \\
1.17(0.90,1.53) \\
1.58(1.21,2.08)^{* * *}\end{array}$ \\
\hline $\begin{array}{l}\text { Region } \\
\text { Central } \\
\text { North } \\
\text { South }\end{array}$ & $\begin{array}{l}1 \text { (Reference) } \\
1.16(0.96,1.41) \\
0.56(0.45,0.69)^{* * *}\end{array}$ & $\begin{array}{l}1 \text { (Reference) } \\
1.03(0.84,1.25) \\
0.53(0.43,0.66)^{* * *}\end{array}$ & $\begin{array}{l}1 \text { (Reference) } \\
0.82(0.65,1.03) \\
0.59(0.47,0.74)^{* * *}\end{array}$ \\
\hline $\begin{array}{l}\text { Residence } \\
\text { Rural } \\
\text { Urban } \\
\end{array}$ & $\begin{array}{l}1 \text { (Reference) } \\
1.03(0.81,1.32)\end{array}$ & $\begin{array}{l}1 \text { (Reference) } \\
0.79(0.59,1.04)\end{array}$ & $\begin{array}{l}1 \text { (Reference) } \\
0.91(0.71,1.17)\end{array}$ \\
\hline $\begin{array}{l}\text { Health insurance cover } \\
\text { No } \\
\text { Yes }\end{array}$ & $\begin{array}{l}1 \text { (Reference) } \\
1.04(0.87,1.24)\end{array}$ & $\begin{array}{l}1 \text { (Reference) } \\
1.05(0.88,1.26)\end{array}$ & $\begin{array}{l}1 \text { (Reference) } \\
1.25(0.99,1.57)\end{array}$ \\
\hline $\begin{array}{l}\text { Media exposure } \\
0-1 \\
2 \\
3-4\end{array}$ & $\begin{array}{l}1 \text { (Reference) } \\
1.24(1.02,1.50)^{*} \\
1.34(1.07,1.68)^{*}\end{array}$ & $\begin{array}{l}1 \text { (Reference) } \\
1.10(0.91,1.33) \\
1.80(1.46,2.23)^{* * *}\end{array}$ & $\begin{array}{l}1 \text { (Reference) } \\
1.03(0.80,1.34) \\
1.62(1.23,2.14)^{* * *}\end{array}$ \\
\hline $\begin{array}{l}\text { Decision making power } \\
\text { Low } \\
\text { High }\end{array}$ & $\begin{array}{l}1 \text { (Reference) } \\
1.32(1.02,1.72)^{*}\end{array}$ & $\begin{array}{l}1 \text { (Reference) } \\
1.23(0.93,1.63)\end{array}$ & $\begin{array}{l}1 \text { (Reference) } \\
0.96(0.70,1.33)\end{array}$ \\
\hline $\begin{array}{l}\text { Tobacco use } \\
\text { No } \\
\text { Yes }\end{array}$ & $\begin{array}{l}1 \text { (Reference) } \\
1.43(1.11,1.84)^{* *}\end{array}$ & $\begin{array}{l}1 \text { (Reference) } \\
1.30(1.02,1.66)^{*}\end{array}$ & $\begin{array}{l}1 \text { (Reference) } \\
1.61(1.21,2.14) * * *\end{array}$ \\
\hline
\end{tabular}

$\mathrm{AOR}=$ Adjusted Odds Ratio; $\mathrm{CI}=$ Confidence Interval; $* * * \mathrm{P}<0.001 ; * * \mathrm{P}<0.01 ; * \mathrm{P}<0.05$ 